\title{
STRATEGI PEMERINTAH DALAM MENINGKATKAN PARTISIPASI MASYARAKAT SEBAGAI UPAYA PENGEMBANGAN PARIWISATA PANTAI MALAGA
}

\author{
Ridhon MB Simangunsong 1 , Elman Nofan Ziliwu² \\ Fakultas Ilmu Sosial dan Ilmu Politik, Universitas HKBP Nommensen \\ ridhon.manguns@gmail.com
}

\begin{abstract}
ABSTRAK: Penelitian ini dilatarbelakangi oleh kurangnya keikutsertaan masyarakat dalam pengembangan pariwisata di Kota Gunungsitoli lebih khususnya masyarakat sekitar Pantai Malaga. Penelitian ini bertujuan untuk mengetahui bagaimana strategi pemerintah Kota Gunungsitoli dalam meningkatkan partisipasi masyarakat sebagai upaya dalam pengembangan pariwisata Pantai Malaga. Pengembangan pariwisata merupakan salah satu tugas dan tanggungjawab dari pemerintah Dinas Pariwisata Kebudayaan Pemuda dan Olahraga. Penelitian ini meggunakan metode deskriptif dengan pendekatan kualitatif. Penelitian ini dikembangkan dengan dimensi perencanaan, implementasi dan evaluasi. Subjek penelitian yang digunakan dalam penelitian ini adalah Pemerintah Dinas Pariwisata Kebudayaan Pemuda dan Olahraga Kota Gunungsitoli, pemilik onjek wisata Pantai Malaga, masyarakat sekitar dan pengunjung objek wisata Pantai Malaga. Penentuan subjek tersebut menggunakan teknik non probability sampling dengan teknik purposive sampling. Teknik pengumpulan data yang digunakan yaitu wawancara, observasi dan dokumen. Berdasarkan hasil penelitian yang diperoleh, maka strategi pemerintah dalam meningkatkan partisipasi masyarakat adalah pembuatan Rencana Pengembangan Pariwisata Daerah yang dibuat berdasarkan hasil MUSRENBANG yang melibatkan masyarakat untuk memperoleh masukan, melakukan sosialisasi baik sosialisasi secara langsung ataupun secara tidak langsung dan melakukan pemerataan sarana dan prasarana untuk mendukung pengembangan pariwisata. Dengan strategi yang diterapkan oleh pemerintah Dinas pariwisata Kota Gunungsitoli diharapkan mampu meningkatkan paritisipasi masyarakat.
\end{abstract}

\section{Kata Kunci : Strategi Pemerintah, Partisipasi Masyarakat, Pengembangan Pariwisata}

\begin{abstract}
The study was set back by a lack of participation in the development of tourism in the cities of gunungsitoli, especially those around the coast of Malaga. The study aims to learn how the gunungsitoli government's strategy in boostering community participation as an effort in developing Malaga beach tourism. The development of tourism is one of the duties and responsibilities of the government of the youth and sports tourism service. The study employs descriptive methods with a qualitative approach. The research was developed with dimensions of planning, implementation and evaluation. The research subject used in the study is the government of the youth tourism service and gunungsitoli city sports administration, the owners of Malaga beach tourism, the local community and visitors to Malaga beach attractions. The identification of the subject is using a nonsampling technique with an observsive sampling. The data-gathering techniques used were interviews, observations and documents. Based on research obtained, the government's strategy to increase community participation is the creation of a plan for development of regional tourism that involves people getting input, whether by direct or indirect socialization, and creating tools and infrastructure to optimize
\end{abstract}

\section{Keywords: Government Strategies, Community Participation, Tourism Development}

\section{PENDAHULUAN}

Indonesia merupakan salah satu Negara yang terdiri dari lima pulau besar, diantaranya Pulau Jawa, Sumatra, Kalimantan, Sulawesi dan Irian Jaya. Selain itu juga terdapat beribu pulau kecil yang terbentang dari Sabang sampai Marauke yang memiliki sumber daya alam yang melimpah serta memiliki keanekaragaman 
bahasa, suku, agama, adat istiadat, dan budaya.Selain memiliki sumber daya alam yang melimpah secara geografis Indonesia terletak cukup strategis yaitu berada di titik silang lalu lintas dan perdagangan dunia.Keanekaragaman serta kekayaan alam yang dimiliki oleh Indonesia tersebut menjadi satu kesatuan wilayah Negara Kesatuan Republik Indonesia (NKRI).Berdasarkan fakta tersebut diatas, selayaknya Indonesia mampu menjadi Negara yang maju dan mampu membawa rakyatnya hidup dalam kesejahteraan.Kekayaaan alam yang dimiliki Indonesia sangat melimpah.Jika hal ini dapat dikelola dengan baik, maka dapat memberi potensi besar dalam meningkatkan pendapatan masyarakat. Dengan begitu masyarakat akan hidup dalam taraf yang baik, dan mampu bersaing dengandunia luar. Selain itu juga masyarakat tidak terlalu tergantung kepada Negara dalam hal iniadalah pemerintah.

Pulau Nias merupakan salah satu daerah tujuan wisata favorit bagi wisatawan baikdomestik maupun luar negeri, terutama bagi penggemar wisata surfing atau pencinta eksotisme pantainya yang mempesona, maupun atraksibudaya dan seni tradisional yang selalu mengundang decak kagum setiappengunjungnya misalnya atraksi Lompat Batu, Tari Perang, Tari Moyo dan lain-lain.Pulau Nias adalah sebuah pulau yang terdapat di barat Pulau Sumatera dan dikelilingi oleh beberapa pulau yang lebih kecil, diantara 27 pulau yang mengelilinyatersebut hanya sekitar 11 pulau saja yang sudah berpenghuni termasuk Pulau Nias sebagai pulau terbesar dan memiliki populasi penduduk yang tinggi, Pulau Nias juga terdiri dari empat kabupaten dan satu kota yakni Kabupaten Nias, Kabupaten Nias Selatan, Kabupaten Nias Barat, Kabupaten Nias Utara, dan Kot a Gunungsitoli. Gunungsitoli adalah ibukota Pulau Nias dan menjadi segala pusat kegiatan dan kebutuhan Pulau Nias.

Beberapa objek wisata yang ada di Kota Gunungsitoli misalnya Pantai Muara Indah, Pantai Charlita, Pantai Bunda, Pantai Malaga, Pantai Hoya, dan Pantai Kaliki. Pantai Malaga merupakan salah satu kawasan objek wisata pantai yang juga berada dalam wilayah Kota Gunungsitoli, Kecamatan Gunungsitoli Idanoi. Keberadaan pantai Malaga banyak dimanfaatkan oleh wisatawan, baik wisatawan lokal maupun wisatawan mancanegara untuk berlibur serta dapat menikmati aneka kuliner khas Pulau Nias. Lokasi pantai Malaga cukup strategis karena lokasi pantai Malaga tidak jauh dari Bandara Binaka Gunungsitoli, hal ini dapat menjadi peluang besar untuk menarik wisatawan dari luar daerah Pulau Nias. Pantai Malaga merupakan pantai yang sangat berpotensi untuk lebih mudah dikembangkan karena Pantai ini menyimpan keindahan tersendiri karena pantainya yang bersih, pasir putihnya yang indah serta tersedianya berbagai macam kuliner khas Nias.

Namun hal ini kurang dapat dimanfaatkan sehingga perkembangan pantai ini pun terbilang biasa-biasa saja. Hal ini dipengaruhi oleh kurangnya partisipasi atau kesadaran masyarakat sekitar untuk ikut bekerja sama dalam mengembangkan pantai Malaga, masyarakat kurang mengerti akan dampak positif 
jika pengunjung semakin meningkat. Namun sebagian kecil juga masyarakat sekitar memanfaatkan keberadaan pantai Malaga ini untuk membuka usaha dalam hal ini menyediakan penginapan bagi wisatawan atau menjual berbagai jenis makanan. Keindahan pantai Malaga memang sudah tidak diragukan lagi karena pemandangannya yang cukup indah serta suasana pantai yang sangat sejuk karena dikelilingi pepohonan yang cukup indah. Namun dalam upaya pengembangan pantai Malaga juga tidak terlepas dari berbagai hambatan hal ini dipengaruhi oleh kurangnya partisipasi masyarakat dalam upaya mengembangkan pariwisata pantai Malaga. Misalnya saja, masyarakat sekitar kurang memiliki sikap yang ramah bagi para pengunjung sehingga hal ini dapat berdampak berkurangnya para pengunjung di pantai Malaga, masyarakat tidak mau tahu akan pentingnya kerja sama dalam pengembangan pantai Malaga serta terkadang terjadi perkelahian antar masyarakat sekitar pantai itu sendiri yang dalam posisinya terjadi di area wisata pantai Malaga, sehingga hal ini dapat menjadi penilaian buruk dari setiap pengunjung yang datang dan secara otomatis dapat mempengaruhi semakin berkurangnya jumlah pengunjung yang datang.

Potensi wisata yang dimiliki oleh masyarakat Kota Gunungsitoli pada dasarnya belum dikelola secara maksimal. Padahal jika mampu dikelola dengan baik maka akanberdampak pada peningkatan ekonomi masyarakat. Kendala yang dimiliki oleh pemerintah Kota Gunungsitoli dalam hal ini Dinas Pariwisata Kebudayaan Pemuda dan Olahraga Kota Gunungsitoli dalam pengembangan Pariwisata. Misalnya saja dalam pengembangan Pantai Malaga yang berlokasi di Kecamatan Gunungsitoli Idanoi diantaranya yaitu, Pertama, kurangnya Sumber Daya Manusia yang berbasis kepariwisataan di Dinas Pariwisata Kebudayaan Pemuda dan Olahraga (DISPARBUDPORA) Kota Gunungsitoli. Kedua, tidak adanya ketersediaan sarana dan prasarana dalam hal sistem informasi seperti website, untuk mempromosikan obyek pariwisata yang ada di Kota Gunungsitoli.Ketiga, kurangnya pelaksanaan pendidikan dan pelatihan (DIKLAT) di Dinas Pariwisata Kebudayaan Pemuda dan Olahraga Kota Gunungsitoli, untukperkembangan pariwisata.Keempat, Dinas Pariwisata Kebudayaan Pemuda dan Olahraga di Kota Gunungsitoli, kurang kerjasama dengan masyarakat, untuk mengadakan pertemuan baik secara formal maupun informal dengan tujuan mengembangkan pariwisata yang ada di Kota Gunungsitoli.Kelima, kurangnya pembinaan dan pengawasan secara berkala dilapangan oleh Dinas Pariwisata Kebudayaan Pemuda dan Olahraga Kota Gunungsitoli.Sehingga Pantai Malaga semakin lama semakin sepi dari pengunjung.Biasanya ramai pada saat hari libur dan hari besar lainnya, namun pada hari biasa pengunjung diperkirakan rata-rata dalam seharinya 5-15 orang.

Selain lingkungan atau lokasi objek pariwisata berada, masyarakat sekitar juga dapat berpengaruh terhadap upaya pengembangan objek wisata di Kota Gunungsitoli, sebab keterlibatan masyarakat sekitar dalam upaya pengembangan objek wisata sangat berpengaruh besar karena selama ini masyarakat tidak mau tau akan pentingnya sikap keramahan ataupun sikap rasa memiliki, sehingga 
dengan keadaan demikian dapat berpengaruh terhadap penurunan jumlah pengunjung.

Berdasarkan permasalahan yang terjadi dilokasi penelitian maka peneliti merumuskan masalah penelitian yaitu Bagaimana Strategi Pemerintah Kota Gunungsitoli Dalam Meningkatkan Partisipasi Masyarakat Sebagai Upaya Pengembangan Pariwisata Pantai Malaga. Adapun tujuan penelitian ini adalah untuk mengetahui strategi pemerintah kota Gunungsitoli dalam meningkatkan partisipasi masyarakat sebagai upaya pengembangan pariwisata Pantai Malaga.

Penelitian ini juga memiliki beberapa manfaat yaitu sebagi berikut :

1. Manfaat secara teoritis

a. Dapat memberikan sumbangan pemikiran ataupun sumbangan ilmu pengetahuan khususnya yang berkaitan dengan proses peningkatan partisipasi masyarakat dalam pengembangan pariwisata.

b. Dapat digunakan bagi para peneliti selanjutnya sebagai bahan pertimbangan mengenai peningkatan partisipasi masyarakat dalam pengembangan pariwisata.

2. Manfaat secara praktis

a. Bagi peneliti, diharapkan dapat menambah wawasan, pengalaman dan pengetahuan tentang strategi peningkatan partisipasi masyarakat sebagai upaya dalam pengembangan pariwisata.

b. Bagi Dinas Pariwisata Kota Gunungsitoli dan Masyarakat sekitar pantai Malaga diharapkan dapat menjadi sebuah masukan positif untuk meningkatkan partisipasi masyarakat sebagai upaya pengembangan pariwisata.

Parawisata secara etimologis dikatakan kata tour berasal dari bahasa Latin yaitu tornare dan dalam bahasa Yunani yaitu tormos yang berarti lathe or circle maksudnya adalah perpindahan dari suatu titik pusat. Sedangkan isme berarti tindakan.Tourdanismedigabungkan menjadi tourism yang berarti perpindahan atau perputaran dari satu titik dan kembali ke titik semula.Sehingga tour menunjukkan suatu perjalanan yang berputar (round trip).

Mathieson and Wall menyebutkan bahwa Pariwisata adalah perpindahan masyarakat untuk sementara ke suatu destinasi di luar tempat normal mereka tinggal dan bekerja untuk melakukan aktivitas di daerah destinasi dengan adanya fasilitas untuk memenuhi kebutuhanya.

Selain itu, pariwisata juga dapat didefinisikan berdasarkan bahasa sansekerta yang terdiri dari dua kata, yaitu kata pari dan kata wisata. Pari yang artinya penuh dan wisata berarti perjalanan, sehingga pengertian secara harafiah pariwisata diaratiakan "penuh dengan perjalanan".Definisi pariwisata yang dipandang dari dimensi spasial merupakan definisiyang berkembang lebih awal dibandingkan definisi-definisi lainnya (Gartner, 1996). Dimensi ini menekankan defenisi pariwisata pada pergerakan wisatawan ke suatu tempat 
yang jauh dari lingkungan tempat tinggal dan atau tempat kerjanya untuk waktu yang sementara. Selain pergerakan ketempat yang jauh dari lingkungan tempat tinggal dan tempat kerja Airey menambahkan kegiatan wisataawan selama berada di destinasi pariwisata sebagai bagian dari pariwisata. Defenisi pariwisata yang dikemukakan oleh word toursm organization (wto) pun memfokuskan pada sisi demand dan sisi spassial, dengan menetapkan dimensi waktu perjalanan yang dilakukan wisatawan, yaitu tidak lebih dari satu tahun berturut-turut.

Dari sisi supply, pariwisata lebih banyak dilihat sebagai industri/bisnis. Defenisi yang dipandang dari sisi industri/bisnis memfokuskan pada keterkaitan antara barang dan jasa untuk memfasilitasi perjalanan wisata. Sementara Nyoman S Pendit dalam bukunya Ilmu Pariwisata memberikan definisi mengenai pariwisata yaitu salah satu jenis industri baru mampu menghasilkan pertumbuhan ekonomi yang cepat dalam penyediaan lapangan kerja, peningkatakan penghasilan, standar hidup serta menstimulasi sector-sektor produktivitas lainnya.

Menurut Paturusi (2001) mengungkapkan bahwa pengembangan adalah suatu strategi yang dipergunakan untuk memajukan, memperbaiki dan meningkatkan kondisi kepariwisataan suatu objek dan daya tarik wisata sehingga dapat dikunjungi wisatawan serta mampu memberikan mafaat bagi masyarakat disekitar objek dan daya tarik wisata maupun bagi pemerintah.

Pengembangan pariwisata bertujuan untuk memberikan keuntungan bagi wisatawan maupun komunitas tuan rumah. Dengan adanya pembangunan pariwisata diharapkan mampu meningkatkan taraf hidup masyarakat melalui keuntungan secara ekonomi yang dibawa ke kawasan tertentu. Pengembangan tersebut hendaknya memeperhatikan berbagai aspek seperti aspek budaya, sejarah dan ekonomi daerah tujuan wisata. Didalam undang-undang No.9 tahun 1990 tentang kepariwisataan disebutkan dalam pasal 1 (5)usaha pariwisata adalah kegiatan yang bertujuan menyelenggarakan jasa pariwisata atau menyediakan atau mengusahakan objek dan daya tarik wisata, usaha barang pariwisata, dan usaha lain yang terkait di bidang tersebut.

Pariwisata terdiri dari lima komponen besar, dimana komponen tersebut merupakan satu kesatuan yang memerlukan keterkaitan, ketergantungan dan keterpaduan yaitu :

1. Atraksi Wisata yaitu daya tarik wisatawan seperti sumber daya manusia, budaya, adat istiadat dan sebagainya.

2. Promosi merupakan suatu rancangan untuk memprkenalkan atraksi yang ditawarkan dan cara bagaimana atraksi dapat dikunjungi. Untuk perencanaan, promosi merupakan bagian yang terpenting.

3. Pasar (Asal Wisatawan) merupakan bentuk analisis mendalam tentang trend perilaku, keinginan, kebutuhan, asal, motivasi, dan lain-lain yang menyangkut wisatawan.

4. Transportasi merupakan suatu yang menyangkut orang dan destinasi pariwisata. 
5. Fasilitas atau pelayanan merupakan pendukung aktivitas pariwisata yang didominasi pihak swasta.

Pelaku pariwisata merupakan semua pihak yang berperan dan ikut terlibat dalam kegiatan pariwisata. Adapun yang menjadi pelaku-pelaku pariwisata sebagai berikut:

1. Wisatawan merupakanpihak pengguna produk dari tempat yang dikunjungi. Motivasi kunjunganya dapat digolongkan untukliburan (rekreasi,studi,agamaatau olahraga dan lain-lain).

2. Industri Pariwisata/Penyedia Jasa adalah pihak yang menghasilkan barang atau jasa bagi para wisatawan. Mereka dapat digolongkan dalam dua golongan utama yaitu :

a. Pelaku langsung, yaitu usaha-usaha wisata yang menawarkan jasa secara langsung kepada wisatawan atau jasanya langsung dibutuhkan oleh wisatawan. Termaksud dalam kategori ini adalah hotel, restoran, biro perjalanan, pusat informasi wisata, atraksi hiburan dan lain-lain.

b. Pelaku tidak langsung, yaitu usaha yang mengkhususkan diri pada produk- produk yang secara tidak langsung mendukung pariwisata, misalnya usaha kerajinan tangan, penerbit buku atau lembaran panduan wisata dan sebagainya.

3. Pemerintah merupakan pihak yang mempunyai otoritas dalam mendukung kegiatan pariwisata baik dalam penyediaan fasilitas maupun dalam hal melakukan sosialisasi kepada pihak yang terkait dalam industri pariwisata. Selain itu, pemerintah juga bertanggungjawab dalam mengawasi dan menentukan arah yang dituju perjalanan pariwisata.

4. Masyarakat local adalah masyarakat yang tinggal dikawasan wisata. Mereka merupakan salah satu aktor penting dalam pariwisata karena sesungguhnya mereka yang menyediakan sebagian besar atraksi sekaligus menentukan kualitas produk wisata. Selain itu, masyarakat lokal merupakan pemilik langsung atraksi wisata yang dikunjungi sekaligus dikonsumsi oleh wisatawan.

WTO memberikan defenisi tentang wisatawan yaitu :

1. Pengunjung adalah setiap orang yang berkunjung kesuatu negara lain dimana ia mempunyai tempat kediaman, dengan alasan melakukan pekerjaan oleh negara yang dikunjunginya.

2. Wisatawan adalah setiap orang yang bertempat tinggal di suatu negara tanpa memandang warga negaranya,berkunjung kesuatu tempat pada negara yang sama untuk jangka waktu lebih dari 24 jam yang tujuan perjalananya dapat diklasifikasikan pada salah satu hal berikut ini.

a. memanfaatkan waktu luang untuk berekreasi, liburan, kesehatan, pendidikan, keagamaan dan olahraga.

b. Bisnis atau mengunjungi kaum keluarga.

3. Darmawisata atau exursionist, adalah pengunjung sementara yang menetap kurang dari 24 jam di negara yang dikunjunginya termasuk orang 
yang berkeliling dengan kapal pesiar, namun tidak termasuk orang yang berkeliling dengan kapal pesiar secara legal.

Di Indonesia, pengertian wisatawan tercantum dalam intruksi presiden RI No.9Tahun 1967, yaitu setiap orang yang bepergian dari tempat tinggalnya untuk berkunjung ketempat lain dengan menikmati perjalanan dan kunjungan itu.

Objek wisata adalah segala sesuatu yang memiliki daya tarik, keunikan dan nilai yang tinggi, yang menjadi tujuan wisatawan datang ke suatu daerah tertentu. Seiring dengan perkembangan industri pariwisata maka muncul berbagai macam objek pariwisata yakni Objek Wisata Alam dan Objek Wisata Sosial Budaya.

1. Objek Wisata Alam

a. Pantai

Pantai adalah sebuah bentuk geografis yang terdiri dari pasir dan terdapat di daerah pesisir laut. Pantai merupakan salah satu objek dan daya tarik wisata yang berkaitan erat dengan aktivitas seperti berjemur diterik matahari, berenang, naik perahu, berfotodan lain-lain.

b. Pegunungan

Pegununganmerupakan salah satu tempat tujuan dari para wisatawan dengan tujuan untuk menikmati pemandangan, mendaki, berkemah ataupun berfoto. Jenis objek wisata ini termaksud gunung berapi dan bukit-bukitdengan keunikan tertentu.

c. Tanah dan Daerah Konservasi merupakan tempat atau lokasi yang berhubungan dengan flora dan fauna misalnya taman safari, kebun binatang, aquarium dan lain-lain.

2. Objek Wisata Sosial Budaya

a. Museummerupakan suatu temapat yang berhubungan dengan aspek alam dan aspek kebudayaan disuatu kawasan atau daerah tertentu. Museum ini berupa arkeologi, sejarah, teknologi, seni dan kerajinan, ilmu pengetahuan dan lain- lain.

b. Peninggalan sejarah purbakala dan monument nasional, gedung sejarah, kota, desa, bangunan dan keagamaan, serta tempat-tempat bersejarah lain seperti bangunan-bangunan kunci.

c. Wisata keagamaan, etnis dan nostalgia, erat kaitannya dengan wisatawan atau pengunjung yang memiliki latar belakang kebudayaan, agama, etnis, dan sejarah yang sama atau hal-hal yang pernah berhubungan dengan masa lalunya.

Objek wisata merupakan daya tarik utama mengapa seseorang datang berkunjung pada suatu tempat.Oleh sebab itu, keaslian dari objek dan atraksi yang ditampilkan harus dipertahankan sehingga wisatawan merasa betah ditempat tersebut.

Kata strategi berasal dari bahasa Yunani yaitustrategria (stratus artinya militer; danag artinya pemimpin), yang dapat diartikan sebagai seni atau ilmu menjadi seorang jenderal. Konsep ini relevan dengan situasi pada zaman dulu yang sering diwarnai perang, dimanajenderal dibutuhkan untuk memimpin suatu 
angkatan perang agar dapat selalumemenangkan perang. Strategi juga bisa diartikan sebagai suatu rencana untuk pembagian dan penggunaan kekuatan militer dan material pada daerah-daerah tertentu untuk mencapai tujuan tertentu. Strategi militer didasarkan pada pemahaman akan kekuatan dan penempatan posisi lawan, kharakteristik fisik medan perang, kekuatan dan karakter sumber daya yang tersedia, sikap orang-orang yang menempati territorial tertentu, serta antisipasi terhadap setiap perubahan yang mungkin terjadi.

Menurut Chandler dalam buku Husein Umar, strategi merupakanalat untuk mencapai tujuan perusahaan dalam kaitannya dengan tujuan jangka panjang, program tindak lanjut serta prioritas alokasi sumber daya.Sedangkan menurut Porter, strategi adalah alat-alat yang sangat penting untuk mencapai keunggulan bersaing. Selain itu juga defenisi yang lebih luas khusus, misalnya dua pakar strategi Hamel Pralhalad, yang mengangkat kompetensi inti sebagai hal penting. Mereka berdua mendefinisikan strategi yang terjemahannya sebagai berikut.

Partisipasi masyarakat merupakan hak dan kewajiban seorang warga negara untuk memberikan kontribusinya kepada pencapaian tujuan kelompok. Sehingga mereka diberi kesempatan untuk ikut serta dalam pembangunan dengan menyumbangkan inisiatif dan kreatifitasnya. Dalam ensiklopedi administrasi disebutkan bahwa arti dari kata partisipasi adalah suatu aktifitas untuk membangkitkan perasaan diikutsertakan dalam kegiatan organisasi, atau ikut sertanya bawahan dalam kegiatan organisasi. Menurut Soekanto (1983) menegaskan bahwa partisipasi adalah pinjaman dari bahasa Belanda "participation" yang sebenarnya dari bahasa Latin "participatio". Perkatan "participatio" terdiri dari dua suku kata yakni partyang berarti bagian dan capare yang berarti mengambil bagian. Kata participatio itu sendiri berasal dari kata kerja "participare" yang berarti ikut serta. Dengan demikian partisipasi mengandung pengertian aktif, yakni adanya kegiatan atau aktifitas.

Ada tiga tradisi konsep partisipasi terutama jika dikaitkan dengan praktek pembangunan masyarakat yang demokratis antara lain :

1. Partisipasi Politik

Partisipasi politik merupakan representasi dalam demokrasi. Tujuannya untuk memengaruhi dan mendudukan wakil rakyat dalam lembaga pemerintahan daripada melibatkan langsung masyarakat dalam proses-proses pemerintahan.

2. Partisipasi Sosial

Partisipasi sosial merupakan keterlibatan masyarakat dalam proses pembangunan. Masyarakat dipandang sebagai beneficiary pembangunan dalam konsultasi atau pengambilan keputusan dalam semua tahapan siklus proyek pembangunan dari penilaian kebutuhan, perencanaan, pelaksanaan sampai pada pemantauan dan evaluasi program.

3. Partisipasi Warga 
Partisipasi warga merupakan proses pengambilan keputusan langsung dalam kebijakan publik. Warga berpatisipasi secara langsung dalam pengambilan keputusan pada lembaga dan proses pemerintah.

\section{METODOLOGI PENELITIAN}

Metode yang digunakan adalah metode deskriptif dengan pendekatan kualitatif atau kasus tunggal. Kasus tunggal merupakankasus yang menyajikan uji krisis suatu teori yang signifikan.Pendekatan kualitatif diartikan sebagai pendekatan yang menghasilkan data, tulisan dan tingkah laku yang dapat diartikan. Penelitian deskriptif digunakan untuk menggambarkan atau melukiskan apa yang sedang diteliti dan berusaha memberikan gambaran yang jelas dan mandalam tentang apa yang sedang diteliti yang menjadi pokok permasalahan.

Penelitian ini dilakukan dikantor Dinas Pariwisata Kebudayaan Pemuda dan Olahraga Kota Gunungsitoli dan di Pantai Malaga. Pemilihan lokasi penelitian ini didasarkan atas pertimbangan peneliti disesuaikan dengan konteks tentang strategi pemerintah dalam meningkatkan partisipasi dalam pengembangan pariwisata.

Dalam penelitian, peneliti tidak menggunakan populasi dan sampel melainkan informan penelitian dikarenakan bentuk penelitian yang dipakai adalah kualitatif. Untuk menentukan sampel/informan yang akan digunakan dalam penelitian, peneliti menggunakan teknik non probability sampling dengan teknik purposive sampling dimana teknik pengambilan sampel sumber data dengan pertimbangan tertentu. Pertimbangan tertentu itu, misalnya orang tersebut dianggap paling tahu tentang apa yang peneliti harapkan, atau mungkin sebagai penguasa sehingga akan memudahkan peneliti menjelajahi objek atau situasi sosial yang akan diteliti.

Oleh karena itu informal penelitian dalam penelitian ini adalah sebagai berikut:

a. Informan Kunci, merupakan mereka yang mengetahui dan memiliki berbagai informasi pokok yang diperlukan dalam penelitian. Dalam penelitian ini penulis menggunakan informan kunci yaitu Kepala Dinas Pariwisata Kebudayaan Pemuda dan Olahraga Kota Gunungsitoli dan Kepala Seksi Pengembangan Potensi dan Promosi Pariwisata Kota Gunungsitoli

b. Informan Utama, dalam penelitian ini penulis menggunakan informan utama yaituPemilik Pantai Malaga.

c. Informan Tambahan, merupakan mereka yang ikut serta dalam pengembangan pantai Malaga. Dalam penelitian ini peneliti menggunakan informan tambahan yaitu Masyarakat sekitar pantai Malaga dan Pengunjung objek wisata Pantai Malaga. 
Dalam setiap penelitian, peneliti diharuskan untuk menguasai teknik pengumpulan data sehingga menghasilkan data yang relevan dengan penelitian.Dalam penelitian ini, peneliti menggunakan jenis data primer dan data sekunder.

a. Data primer adalah data yang secara langsung memberikan data kepada peneliti berupa catatan hasil wawancara yang diperoleh melalui wawancara yang dilakukan.

b. Data sekunder adalah data yang tidak memberikan informasi secara langsung kepada peneliti.Data sekunder ini berupa hasil pengelolaan lebih lanjut dari data primer yang disajikan dalam bentuk lain atau dari orang lain. Data ini digunakan untuk mendukung informasi dari sumber data primer yang diperoleh dari wawancara.Peneliti juga menggunakan data sekunder dari hasil studi pustaka dimana peneliti membaca literatureyang dapat menunjang penelitian.

Langkah-langkah pengumpulan data meliputi usaha membatasi penelitian, pengumpulan informasi melalui, observasi, wawancara, baik yang terstruktur maupun tidak, dokumentasi, serta usaha merancang protocol untuk merekam atau mencatat informasi.

Prosedur-prosedur pengumpulan data dalam penelitian Kulitatif melibatkan empat jenis strategi :

a. Observasi Kualitatif merupakan observasi yang didalamnya penelitian langsung turun ke lapangan untuk mengamati perilaku dan aktivitas individu-individu di lokasi penelitian.

b. Dalam wawancara kualitatif Peneliti dapat melakukan face to face interview (wawancara berhadap-hadapan) dengan partisipan.

c. Selama proses penelitian, peneliti juga bisa mengumpulkan dokumendokumen kualitatif. Dokumen ini bisa berupa dokumen publik seperti koran, makalah, atau laporan laporan kantor, atau email.

Analisis data adalah proses mencari dan menyusun secara sistematis data yang diperoleh dari wawancara, catatan lapangan, dan dokumentasi, dengan cara mengorganisasikan data ke dalam kategori, menjabarkan ke dalam unit-unit, melakukan sintesa, menyusun ke dalam pola, memilih mana yang penting dan yang akan dipelajari dan membuat kesimpulan sehingga mudah dipahami oleh diri sendiri maupun orang lain.

\section{HASIL PENELITIAN}

Gunungsitoli merupakan kota tertua dan terbesar yang ada di Kepulauan Nias. Setelah ditingkatkan statusnya dari kecamatan menjadi kota otonom, popularitas kota yang dibentuk berdasarkan Undang-Undang Nomor 47 Tahun 2008 ini semakin melejit. Tak hanya pada tataran lokal atau regional. Bahkan ditingkat internasional Kota Gunungsitoli banyak menjadi bahasan diskusi. Berdasarkan catatan sejarah Gunungsitoli atau sering disebut Luaha sudah 
dikenal dan dikunjungi sejak abad ke 18. Posisi kota Luaha ini terletak pada muara sungai Nou atau pasar Gunungsitoli saat ini. Pada saat itu ada tiga marga dominan yang menghuni kota Luaha, yaitu Harefa, Zebua, dan Telaumbanua atau lebih dikenal dengan Sitolu Tua.

Kota Gunungsitoli memiliki luas wilayah sebesar $284,78 \mathrm{~km}^{2}$, Kota Gunungsitoli memiliki enam kecamatan, yaitu Kecamatan Gunungsitoli, Kecamatan Gunungsitoli Idanoi, Kecamatan Gunungsitoli Selatan, Kecamatan Gunungsitoli Barat, Kecamatan Gunungsitoli Alo'oa dan Kecamatan Gunungsitoli Utara, yang terdiri dari 98 Desa dan 3 kelurahan. Perkembangan penduduk dalam suatunegara baik negaraBerkembang maupun Negara Maju, selalu dipengaruhi oleh tingkat kelahiran, kematian dan migrasi.Pertumbuhan penduduk dapat menambah jumlah tenaga kerja yang dibutuhkan, namun di lain pihak dapat menimbulkan permasalahan-permasalahan sosial, ekonomi, budaya dan pendidikan.

Tabel 1. Jumlah Penduduk dan Laju Pertumbuhan Penduduk Menurut Kecamatan di Kota Gunungsitoli 2010, 2014, dan 2015

\begin{tabular}{|c|c|c|c|c|c|c|}
\hline \multirow[t]{2}{*}{ No } & \multirow[t]{2}{*}{ Kecamatan } & \multicolumn{3}{|c|}{ Jumlah Penduduk } & \multicolumn{2}{|c|}{$\begin{array}{c}\text { Laju } \\
\text { Pertumbuhan } \\
\text { Penduduk Per Tahun } \\
(\%)\end{array}$} \\
\hline & & 2010 & 2014 & 2015 & $2010-2015$ & 2014-1015 \\
\hline 1. & Gunungsitoli Idanoi & 21.482 & 22.843 & 23.147 & 7.75 & 1.33 \\
\hline 2. & Gunungsitoli Selatan & 13.739 & 14.611 & 14.808 & 7.78 & 1.35 \\
\hline 3. & Gunungsitoli Barat & 7.436 & 7.906 & 8.011 & 7.73 & 1.33 \\
\hline 4. & Gunungsitoli & 60.625 & 64.467 & 65.333 & 7.77 & 1.34 \\
\hline 5. & Gunungsitoli Alo'oa & 6.708 & 7.131 & 7.266 & 7.72 & 1.33 \\
\hline 6. & Gunungsitoli Utara & 16.212 & 17.23 & 17.470 & 7.76 & 1.35 \\
\hline
\end{tabular}

Sumber : BPS Kota Gunungsitoli

Gunungsitoli Idanoi merupakan sebuah daerah yang memiliki potensi wisata alam yang mampu menarik wisatawan baik lokal maupun mancanegara untuk datang mengunjungi daerah wisata tersebut. Pantai Malaga berlokasi di jalan Pelud Binaka kilometer 15 Desa Simanaere Kecamaatan Gunungsitoli Idanoi yang salah satu objek wisata yang ada di Kota Gunungsitoli. Pantai Malaga merupakan objek wisata yang cukup Indah yang dapat dimanfaaatkan oleh pengunjung untuk bersantai baik bersama teman- teman atau bersama keluarga.

Objek wisata Pantai Malaga merupakan salah satu objek wisata yang baru dibuka. Objek wisata Pantai Malaga mulai dibuka pada tahun 2010. Tak lama kemudian objek wisata Pantai Malaga ini mulai dikenal oleh banyak masyarakat sehingga pada petengahan tahun 2011 objek Wisata pantai Malaga semakin banyak pengunjung namun pada tahun 2013 pengunjung objek wisata Pantai Malaga mengalami penurunan. Pengunujung objek wisata pantai Malaga rata-rata 
5 sampai 15 orang per hari kecuali pada hari libur dan hari besar pengunjungnya bisa mencapai ratusan orang.

Objek wisata pantai Malaga juga memiliki bebagai fasilitas yang disediakan yaitu adanya tempat penginapan, pondok untuk bersantai, kamar mandi untuk umum, ayunan, serta restoran. Di lokasi pantai Malaga juga menyediakan berbagai macam kuliner yang cukup menggiurkan para pengunjung. Pengelola objek wisata Pantai Malaga juga memiliki karyawan sebanyak 10 orang yang terdiri dari 4 orang laki-laki dan 6 orang perempuan.

\section{PEMBAHASAN}

Perencanaan merupakan proses mendefinisikan tujuan organisasi, membuat strategi untuk mencapai tujuan organisasi, dan mengembangkan rencana aktivitas kerja organisasi. Berdasarkan penelitian yang dilakukan oleh peneliti dimana pada tahap perencanaan membahas tentang proses penyusunan strategi, menentukan tujuan yang ingin dicapai dan menentukan sumber daya yang dibutuhkan.

Menurut Chandler, strategi merupakan suatu alat untuk mencapai tujuan perusahaan dalam kaitannya dengan tujuan jangka panjang, program tindak lanjut serta prioritas alokasi sumber daya. Dalam kaitanya dengan penelitian yang dilakukan oleh peneliti diketahui bahwa strategi yang disusun oleh pemerintah Dinas Pariwisata bertujuan untuk pencapain tujuan yaitu meningkatkan jumlah pengunjung serta meningkatan kesejahteraan masyarakat.

Pada proses penyusunan strategi yang dilakukan oleh pemerintah Dinas Pariwisata maka pemerintah Dinas Pariwisata melibatkan masyarakat guna memperoleh saran atau masukan yang diinginkan oleh masyarakat. Pada tahap penyusunan strategi yang dilakukan pemerintah Dinas Pariwisata selalu beranjak dari hasil MUSRENBANG (Musyawarah Perencanaan Pembangunan) karena hasil dari musyawarah ini yang akan dijadikan sebagai patokan untuk menyusun strategi. Dalam pelaksanaan MUSRENBANG ini melibatkan masyarakat meskipun masyarakat dalam hal ini bukan masyarakat secara umum melainkan masyarakat dengan sistem perwakilan yang terdiri dari Kepala Desa, Tokoh Agama, Tokoh Masyarakat serta tokoh lainya yang dianggap mampu mewakili suara dari masyarakat.

Keikutsertaan masyarakat dalam kegiatan MUSRENBANG sangat diperlukan karena pada dasarnya masyarakat yang menjadi obek atau sasaran dari setiap kebijakan yang dikeluarkan oleh pemerintah.Oleh sebab itu, dalam pengambilan setiap keputusan selalu dipertimbangkan atas berbagai macam kritikan dan masukan dari masayakat.

Berdasarkan hasil wawacara yang dilakukan oleh peneliti, yang menjadi tujuan utama dalam pengembangan pariwisata di Kota Gunungsitoli adalah meningkatkan jumlah pengunjung, baik pengunjung domestik maupun pengunjung mancanegara serta membantu meningkatkan perekonomian masyarakat, karena banyaknya pengunjung dapat berpengaruh terhadap 
peningkatan pendapatan masyarakat. Wisatawan yang semakin banyakakan bepengaruh terhadap tingkat pendapat masyarakat maka hal ini menjadi salah satu prioritas utama dari Dinas Pariwisata untuk meningkatkan jumlah pengunjung karena hal ini diyakini mampu memberi pengaruh terhadap kesejahteraan masyarakat.

Berdasarkan Undang-Undang Republik Indonesia Nomor 10 Tahun 2009 tentangkepariwisataan digariskan bahwa pembangunan pariwisata perlu ditingkatkan untuk memperluas kesempatan kerja dan kesempatan berusaha, meningkatkan penerimaan devisa serta memperkenalkan alam kebudayaan bangsa Indonesia.

Didalam melaksanakan setiap program dari Dinas Pariwisata juga tidak terlepas dari besarnya anggaran yang diperoleh, karena hal ini dapat berpengaruh terhadap proses pelaksanaan program yang direcanakan. Sesuai dengan hasil wawancara yang diperoleh oleh peneliti, pemerintah Dinas Pariwisata masih kekurangan anggaran sehingga untuk melaksanakan setiap program yang direncanakan sangat terbatas. Namun keadaan ini masih dimaklumi oleh aparat pemerintah Dinas Pariwisata karena hal ini juga dipengaruhi oleh tingkat pendapatan Kota Gunungsitoli yang masih rendah.

Upaya untuk melakukan pengembangan pariwisata di Kota Gunungsitoli juga tidak terlepas dari pengaruh tingkat partisipasi masyarakat, karena tingkat partisipasi masyarakat dapat berpengaruh terhadap banyaknya jumlah pengujung yang datang.Upaya untuk meningkatkan partisipasi masyarakat terus dilakukan oleh pemerintah Dinas Pariwisata Kota Gunungsitoli baik melalui sosialisasi secara langsung maupun sosialisasi secara tidak langsung melalui radio.Berdasarkan hasil wawancara yang dilakukan oleh peneliti tujuan utama yang diharapkan oleh masyarakat sekitar Pantai Malaga yaitu adanya lowongan kerja, karena masyarakat berharap dapat terbantu perekonomiannya.

Dalam pelaksanaan pengembangan pariwisata juga membutuhkan kinerja yang baik dari pemerintah. Kinerja yang baik dapat diukur melalui produktivitas, kualitas layanan, responsivitas, serta responsibilitas Dinas Kebudayaan dan Pariwisata dalam pelayanannnya kepada masyarakat.Kinerja yang baik juga sangat penting untuk pengelolaan/pengembangan obyek dan daya tarik wisata serta pengembangan sumberdaya manusia bidang pariwisata.Hal-hal tersebut merupakan tanggung jawab yang harus diemban oleh Pemerintah dalam hal ini Dinas Pariwisata Kebudayaan Pemuda dan Olahraga Kota Gunungsitoli dalam upaya pencapaian tujuan meningkatkan jumlah pengunjung wisatawan di Kota Gunungsitoli.

Implementasi merupakan suatu tindakan atau pelaksanaan rencana yang telah disusun dengan cermat dan rinci. Berdasarkan Undang-Undang Republik Indonesia Nomor 10 Tahun 2009 tentangkepariwisataan digariskan bahwa pembangunan pariwisata perlu ditingkatkan untuk memperluas kesempatan kerja dan kesempatan berusaha, meningkatkan penerimaan devisa serta memperkenalkan alam kebudayaan bangsa Indonesia. Sesuai dengan undang- 
undang tersebut maka dalam hal ini pemerintah Dinas Pariwisata sangat dibutuhkan strategi yang mampu memberi pengaruh terhadap pengembangan pariwisata khususnya di Kota Gunungsitoli. Tentu didalam melaksanakan berbagai strategi atau program yang telah direncanakan sebelumnya tidak pernah terlepas dari berbagai kendala, sama halnya dengan yang dialami oleh aparat pemerintah Dinas Pariwisata Kota Gunungsitoli yang masih kekurangan anggaran sehingga hal itu berpengaruh terhadap kualitas dari pelaksanaan strategi yang telah direncanakan.

Berdasarkan hasil dari wawancara yang dilakukan peneliti, objek wisata yang ada di Kota Gunungsitoli semakin lama semakin bertambah. Selain itu aparat pemerintah Dinas Pariwisata menilai sosialisasi-sosialisasi yang dilakukan selama ini sudah mampu memberi pengaruh terhadap peningkatan partisipasi masyarakat dalam upaya pengembangan pariwisata.

Berdasarkan penilaian dari pemerintah Dinas Pariwisata Kota Gunungsitoli sangat berbeda dengan penilaian pemilik objek wisata Pantai Malaga dan juga Masyarakat sekitar Pantai Malaga.Pemilik objek wisata Pantai Malaga dan masayarakat sekitar menilai sosialisasi yang dilakukan oleh pemerintah Dinas Pariwisata Kota Gunungsitoli dianggap tidak terlalu berpengaruh terhadap peningkatan partisipasi masyarakat.Meskipun demikian upaya untuk meningkatkan partisipasi masyarakat terus dilakukan oleh pemerintah Dinas Pariwisata Kota Gunungsitoliyang dilakukan melalui sosialisasi secara langsung atau sosialisasi secara tatap muka terhadap masyarakat dan sosialisasi tidak langsung atau sosialisasi yang dilakukan melalui siaran radio.

Keikutsertaan masyarakat dalam kegiatan MUSRENBANG juga menjadi salah satu strategi dari pemerintah Dinas Pariwisata untuk mendengarkan apa yang menjadi saran atau hal yan menjadi keluhan dari masyarakat sebagai upaya dalam pengembangan pariwisata di Kota Gunungsitoli. Sesuai dengan hasil wawancara yang dilakukan oleh peneliti, pemilik objek wisata Pantai Malaga juga terus berupaya untuk meningkatkanpartisipasi masyarakat. Dalam hal ini pemilik objek wisata Pantai Malaga melakukan pendekatan terhadap masayarakat sekitar dengan cara memberikan peluang bagi masyarakat untuk bekerja (misalnya dalam pembangunan tempat penginapan) selain itu juga sebagian dari karyawanya adalah berasal dari masayrakat sekitar. Tidak hanya itu upaya terus dilakukan oleh pemilik objek wisata dengan cara kerja sama, kerja sama dalam ini adalah pada saat masyarakat sekitar membutuhkan bantuan, misalnya dalam pelaksanaan pesta pernikahan tentu membutuhkan tenda ataupun kursi dan berbagai peralatan yang dibutuhkan dalam pesta pernikahan. Dalam hal ini pemilik objek wisata Pantai Malaga membantu masyarakat sekitar dengan cara meminjamkan peralatan atau perlengkapan yang dibutuhkan tanpa memungut biaya. Dengan cara yang dilakukan oleh pemilik objek wsiata Pantai Malaga ini yakinmampu meningkatkan partisipasi masyarakat. 
Beberapa faktor yang mendukung pelaksanaan strategi meningkatkan partisipasi masyarakat oleh Dinas Pariwisata Kebudayaan Pemuda dan Olahraga Kota Gunungsitoli adalah:

a. Adanya dukungan dari Instansi terkait. Misalnya Dinas Kebudayaan dan Pariwisata Kota Gunungsitoli selaku dinas yang diberi wewenang oleh Walikota Kota Gunungsitoli untuk mengembangkan pariwisata Kota Gunungsitoli melakukan kerjasama dengan Dinas Perindustrian dan Perdagangan untuk mengadakan sosialisasi tentang bisnis atau usaha kepariwisataan.

b. Adanya UU Otonomi Daerah yang secara langsung berimbas terhadap kewenangan Pemerintah Kota Gunungsitoli untuk mengembangkan dan membangun segenap potensi yang sekiranya dapat meningkatkan Pendapatan Asli Daerah (PAD), termasuk juga dalam pengembangan dan pembangunan potensi pariwisata Kota Gunungsitoli.

Selain faktor-faktor pendukung yang telah diuraikan sebelumnya, maka dalam pelaksanaan strategi meningkatkan partisipasi masyarakat juga mengalami hambatan, berikut adalah faktor-faktor penghambat yang dimaksudkan:

a. Dana atau anggaran yang diperoleh Dinas Pariwisata Kebudayaan Pemuda dan OlahragaKota Gunungsitoli untuk melakukan promosi serta dalam menjalankan programnya masih kurang.

b. Pemanfaatan jaringan informasi dan promosi pariwisata belum optimal. Hal ini disebabkan karena keterbatasan dana yang ada, sehingga untuk menjalankan setiap strategi sangat terbatas.

c. Kurang adanya kerja sama antara pihak pemerintah Dinas Pariwisata Kota Gunungsitoli dengan pemilik objek wisata dan juga masyarakat sekitar objek wisata.

Evaluasi merupakan proses penilaian. Dalam sebuah organisasi evaluasi dapat diartikan sebagai proses pengukuran akan evektivitas strategi yang digunakan dalam upaya mencapai tujuan organisasi, dari hasil pengukuran tersebut akan digunakan sebagai analisis situasi program berikutnya.

Sesuai dengan strategi yang telah dilakukan oleh pemerintah Dinas Pariwisata selama ini tidak sepenuhnya tujuan yang diharapkan dapat tercapai, hal itu terbukti berdasarkan hasil dari wawancara yang dilakukan oleh peneliti terhadap masyarakat yang menyatakan bahwa strategi dari pemerintah Dinas Pariwisata Kota Gunungsitoli kurang efektif. Tidak hanya itu, pemilik objek wisata Pantai Malaga juga memiliki penilaian yang sama yaitu strategi yang dilakukan pemerintah selama ini masih kurang efektif.

Penilaian yang dilakukan oleh masyarakat terhadap program pemerintah merupakan suatu keadaan dimana hal yang diinginkan oleh masyarakat tidak sesuai dengan yang diharapkan.Strategi yang dilakukan oleh pemerintah dinilai kurang efektif karena pada dasarnya strategi tidak pernah terlepas dari berbagai hambatan. Sesuai dengan hasil wawancara yang dilakukan 
oleh peneliti terhadap aparat pemerintah Dinas Pariwisata Kota Gunungsitoli menjelaskan bahwa hal yang menjadi kendala dalam menjalankan strategi atau program dari Dinas Pariwisata adalah masalah anggaran atau dana, anggaran untuk Dinas Pariwisata masih sangat kecil sehingga hal ini berdampak pada pelaksanaan setiap program yang dilakukan, artinya pihak dari Dinas Pariwisata akan terbatas dalam menjalankan setiap program yang diinginkan.

Berdasarkan hasil wawancara yang dilakukan oleh peneliti terhadap masyarakat sekitar Pantai Malaga juga menilai bahwa strategi yang dilakukan oleh pemerintah belum sesuai dengan diharapkan. Masyarakat menilai strategi yang dilakukan oleh pemerintah tidak terlalu berdampak terhadap peningkatan partisipasi masyarakat. Walaupun demikian upaya terus dilakukan oleh pemerintah kota Gunungsitoli karena upaya untuk melakukan pengembangan pariwisata Kota Gunungsitoli sudah menjadi tugas dan kewajiban dari aparat pemerintah Dinas Pariwisata Kebudayaan Pemuda dan Olahraga.

Masyarakat sekitar pantai Malaga berharap strategi yang dilakukan oleh pemerintah segera diubah atau diperbaiki kembali. Harapan masyarakat agar setiap strategi yang dikeluarkan oleh pemerintah mampu berdampak positif secara langsung untuk masyarakat misalnya penyediaan lapangan kerja sehingga ekonomi dapat terbantu.

\section{DAFTAR PUSTAKA}

Creswell, John. 2014. Research Design Pendekatan Kualitatif, Kuantitatif dan Mixed. Yogyakarta: Pustaka Pielajar. Cetakan: IV. Edisi Ketiga

Hadinoto, Kusudianto. 1996. Perencanaan Pengembangan Destinasi Pariwisata. Jakarta: UI-Press. Harrison, Lisa. 2009. Metodologi Penelitian Politik. Jakarta: Kencana. Cetakan: II

Indrawijaya, A. Indrawijaya Dan Juni, Pranoto. 2011.Revitalisasi Administrasi Pembangunan. Jakarta: Alfabeta. Cetakan I

Marpaung, Happy. 2000. Pengetahuan Kepariwisataan. Bandung: Alfabeta. Cetakan: I Ngusmanto. 2015. Pemikiran \& Praktik Administrasi Pembangunan. Jakarta: Mitra Wacana Media.

Soekadijo, R.G. 1996. Anatomi Pariwisata. Jakarta: PT Gramedia PustakaUtama. Sugiyono. 2010. Metode Penelitian Kuantitatif Kualitatif dan R\&D. Bandung: Alfabeta. Cetakan: X

Utama, I Gusti Rai dan Ni Made Eka M. 2012. Metodologi Penelitian Pariwisata \& Perhotelan. Yogyakarta: Andi.

Zubaedi. 2014. Pengembangan Masyarakat. Jakarta: Kencana. Cetakan: II 